\title{
Interactive Effects of Transactional Leadership and Work Meaningfulness on Job Performance
}

\author{
Dr. NADEEM AHMED AWAN \\ Assistant Professor, Foundation University Islamabad, Pakistan \\ Email: dr.nadeem.ahmed@fui.edu.pk \\ Tel: +923455556216
}

TARIQ JAMIL

University of Wah, Wah Cantt, Pakistan.

\begin{abstract}
AKRAM SADDIQUE
International Islamic University, ISB, Pakistan.

Abstract

Based on social exchange theory, current study examined the impact of transactional leadership on supervisor rated job performance of employees. Moreover, moderating role of work meaningfulness between this linkage is verified. Primary data from 240 faculty members were collected from different private and public sector universities of Islamabad, Rawalpindi, Lahore \& Sialkot. Simple random sampling technique was used. Data were analyzed using SPSS and Hayes's PROCESS. Correlations \& Regression analysis were applied. The results bolstered the hypothesis of the study. Findings revealed that transactional leadership has a positive impact on job performance of the faculty members. Further, work meaningfulness is proven its moderating role between transactional leadership and job performance. The study will help the managers/leaders in Higher Education Sector to understand the role of transactional leadership and work meaningfulness for improving performance of the faculty members.
\end{abstract}

Keywords: Transactional Leadership, Work Meaningfulness, Supervisor Rated Job Performance, Social Exchange Theory.

\section{Introduction}

Leadership, being a universal phenomenon, has received great attention of researchers and practitioners (Antonakis, 2017). Since decades, leaders have been glorified and considered as a positive force (Bligh et al., 2007). Leadership research has been the topic of discussion of many researchers since past (Howell \& Avolio, 1993; Schriesheim, Castro, \& Cogliser, 1999). Leaders provide an environment where followers become enablers to perform and put efforts to achieve the organizational goals and objectives. (Alrowwad \& Abualoush; 2020). Thus, organizations need to understand and develop such leadership styles or behaviors to achieve desired job/organizational related outcomes. Transactional leadership is a common leadership style that has been applied in organizations (Young et al., 2021). It is defined as "Transactional leadership means managing transactions between the organisations and its members through contingent rewards." (SS Khanka, 2006). Transactional leaders believe on provision of benefits and rewards as a result of successful completion of tasks and objectives (Bass \& Avolio, 1990). However, researchers argue that still there is need to study the role of transactional leader on followers' performance (Young et al., 2021). This linkage is important to study as followers' performance is key to the organizational success (Longe, 2014). Thus, current research is to explore the role of transactional leadership on job performance of the faculty members. Further, it has a support of social exchange theory (SET) as it cares our argument 
that under transactional leadership, follower will perform better because of their mutual exchange of benefits (Young et al., 2021).

However, for deep understanding of transactional leadership-job performance relationship, moderating or mediating role of additional variables can become more useful. Demirtas et al (2017) states that employees' perceived work meaningfulness has a significant influence on employees' performance related behaviors. Work meaningfulness is a subjective state that comes in the result of higher positivism in an organization, an individual associates with work (Kira;2012). For example, for some individuals the job of a teacher is development of the nation and the nation's development is experienced as positive for those individuals. Scholars argue that work meaningfulness behaviors are the main source required to gain organizational success in the ever-changing economic environment of the world (Frese \& Fay, 2001, Crant, 2000). Work meaningfulness is positively related with job related behaviors of the people (Duffy et al., 2012). Thus, based on close connection of transactional leadership and work meaningfulness with job related outcomes, work meaningfulness is taken as a moderating variable to see its role in transactional leadership-job performance relationship.

Thus, purpose of present research is to verify the direct role of transactional leadership on job performance as well moderating role of work meaningfulness in transactional leadership-job performance relationship. The relationship is important as transactional leaders are task oriented and work meaningfulness is about associating the work with positive things. Therefore, jointly both can have strong impact on job performance of the faculty members.

\section{Research Objectives}

- To examine how transactional leadership effect on supervisor rated job performance of the faculty members?

- To investigate the moderating effects of work meaningfulness in the linkage between transactional leadership and supervisor rated job performance of the faculty members?

\section{Research Questions}

- Does transactional leadership have a positive influence on supervisor rated job performance of the faculty members?

○ Does work meaningfulness plays moderating role in the linkage between transactional leadership and supervisor rated job performance of the faculty members?

\section{Literature Review}

\section{Transactional Leadership (TL)}

Leadership, is a worldwide phenomenon and therefore has got high attention from academicians as well as the practitioners across the world (Antonakis, 2017). Since decades, leaders have been glorified and considered as a positive force (Bligh et al., 2007; Bass \& Avolio, 1990). This is the reason that leadership has remained the topic of discussion among scholars of the past (Bass \& Avolio, 1990; Howell \& Avolio, 1993; Schriesheim, Castro, \& Cogliser, 1999). Leaders play a critical role in providing such working environment where their followers become enablers to perform and put efforts in achieving the strategic goals of the firms. (Alrowwad \& Abualoush; 2020). Therefore, firms in all the times have a need to understand and encourage such leaders or leadership styles to achieve desired job/organizational related outcomes. According to a recent meta-analytic study, TL has largely been applied in organizations but still needed to study (Young et al., 2021). Transactional leadership is defined as "Managing transactions between the organisations and its members through contingent rewards." (SS Khanka, 2006). 
Transactional leaders believe on provision of benefits upon task accomplishment (Bass \& Avolio, 1990). Such leaders devote their efforts on completion of tasks by incorporating provision of rewards to enhance the workers' performance (Bass \& Avolio, 2000). This style revolves around the phenomena of power and authority. Such leaders develop systems which are based on tasks and rewards linkage (Young et al., 2021). These leaders highlight the definition of goals, rules and regulations and standards to be achieved. (Bass, 1997). Transactional leaders concentrate on execution of work to increase performance (Bass \& Avolio, 2000). TL construct is exchange of work and rewards and therefore has a strong support of social exchange theory.

\section{Work Meaningfulness (WM)}

Work meaningfulness can be defined as how important a particular work is for an individual at certain period of time during his life (Bellah, Madsen, Sullivan, Swidler, \& Tipton, 1985). Work meaningfulness also refers to how important and attractive that work is for the individual in order to achieve the desired results from his/her work (Rosso et al., 2010).

Employees' perceived WM has a significant influence on employees' performance related behaviors (Demirtas et al., 2017). Work meaningfulness is a subjective state and have no connection with the objective state (Kira., 2012). It comes in result of positivism in the organization (Kira; 2012). Furthermore, he argues that in result of WM, people show willing to associate it with positive things. For instance, the perception of some teachers about their job is nation building and this mindset of societal contribution is experienced as positive for such teachers. It is argued by the scholars that work meaningfulness behaviors are the main source to attain organizational success in the ever-changing economic environment (Frese \& Fay, 2001, Crant, 2000). Work meaningfulness is positively connected with job related behaviors (Duffy et al., 2012). Thus, work meaningfulness has been taken as moderating variable in this study.

\section{Job Performance}

The notion of job performance is highly recognized in the field of management and is related with the job behaviors as well as work related outcomes (Johari, Tan, \& Zulkarnain, 2018; Jamal, 2007; William, 2002). This construct covers both contextual as well as task performance and deemed one of the most important outcome variables (Johari, Tan, \& Zulkarnain, 2018). Job performance means to attain the desired level of organizational outcomes (Mwita, 2000). Hasibuan, (2000) argues that job performance is the effort directed towards achieving the end results based on skills and expertise of the individuals within the given time and allotted resources at the disposal of the individuals. Mangkunagara (2000) concluded that job performance is the result of an individual's input to the output produced within the desired levels of quality standards so as to fulfill his work responsibilities. Jackson at al (1999) explained work performance as the amount of work achievement of an individual as a result of his whole hearted efforts. Scholars believe that performance gets its effects mostly from environment during which the individuals play their roles (Cummings and Schwab, 1973; Whetten and Cameron, 1998). It was also found that for any successful organization the role of leadership effectiveness was a key to success (Maritz, 1995; Ristow et al., 1999).

\section{Transactional Leadership \& Job Performance}

Moreover, various researchers found out that effective leadership behaviors contribute well in achieving the desired outcomes from the followers (Maritz, 1995; Ristow, et al., 1999). Bass (1997) tells that leadership is the attraction point of attraction for groups to perform better through the influence of a personality and through encouragement to accept the desired behaviors. TL has significant effect on job performance as an employee who is committed and satisfied performs batter than the others (Walumbwa \& Hartnell, 2011). For any organization to survive successfully in this competitive business environment the high performance of its employees is the key to success. A number of models and theories have established a connection between leadership and performance (Rejas et al., 2006; Gadot, 2007). However, the magnitude of effect 
on the employees' job performance varies from one leadership style to another (Yammarino, Spangler, \& Dubinsky, 1998).

Transactional leaders devote their efforts on completion of tasks by incorporating provision of benefits \& rewards for increased performance (Bass \& Avolio, 2000). Transactional leaders contribute well in the improvement of job performance as this leadership style is task oriented and demands for work accomplishments. Transactional leaders are to develop systems on the basis of tasks and rewards linkage (Young et al., 2021). This argument has a strong support of social exchange theory (SET) as well because the theory talks about exchange of cost and benefits for work related outcomes. Different studies confirmed the relationship between TL and job performance (Liao \& Chuang, 2007; Schaubroeck, Lam \& Cha, 2007; Judge \& Piccolo, 2004).

However, according to very recent meta-analytic study, TL has been largely applied in organizations but still needed to study (Young et al., 2021).

Hypothesis 1: Transactional leadership is positively associated with supervisor rated job performance of the faculty members.

\section{Moderating Role of Work Meaningfulness}

Workers who have a sense of work meaningfulness put positive influence on performance related behaviors (Demirtas et al., 2017). WM might put invigorating impact upon job related outcomes like job satisfaction or performance (Clercq et al., 2019). According to Kira (2012), at the time when individuals feel that their work is meaningful, associate this with positive things. Individuals who sense that their work is meaningful put their positive job-related efforts for the organization (Koopman et al., 2016). However, those individuals who have low level of work meaningfulness may lack in exerting their full efforts for the organization as their positive feelings towards such efforts are passive (Clercq et al., 2019). Moreover, WM is positively related with job related behaviors (Duffy et al., 2012). Therefore, based on close connection of transactional leadership and work meaningfulness with job related outcomes, work meaningfulness is taken as a moderating variable to see its role in strengthening or weakening the linkage between TL and JP.

Hypothesis 2: Work meaningfulness moderates the linkage between transactional leadership and supervisor rated job performance.

\section{Theoretical Framework}

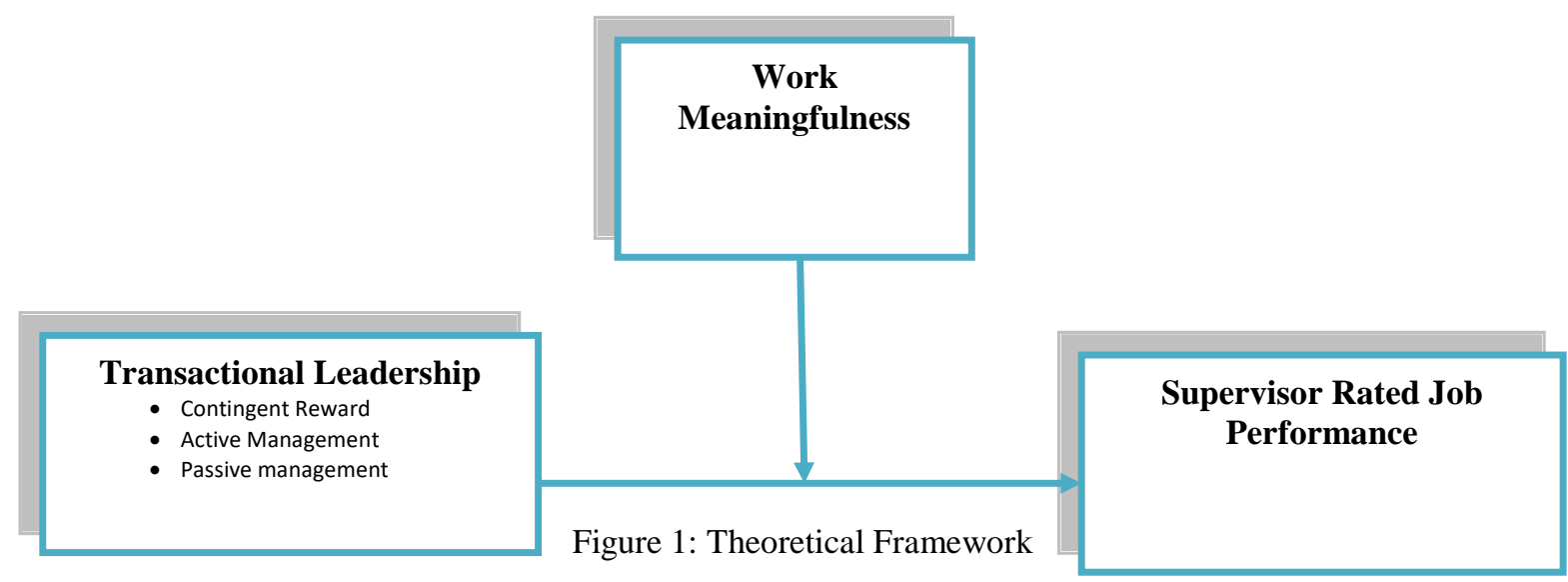




\section{Methods}

\section{Sample and Data Collection}

Respondents of the study were faculty members from different public and private higher education institutitons of Pakistan. The reason is that faculty members play critical role in the societal development of any country.

The study will be helpful to improve the job performance of faculty members that will ultimately equip the students in their personal and professional growth. The chosen institutions/univerisites are located in Islamabad, Rawalpindi, Lahore \& Sialkot. Data were gathered through self adminisntrated questionnaires using simple random sampling technique. This technique is applied due to limited population size. Here, the sample size of the study was taken as 240 faculty members.

Transactional leadership, the independent variable and work meaninfulness, the moderating variable were self reportedly measured. However, job performance, the dependant variable was supervisor rated.

\section{Measures}

Measures of the study were adopted from the ealrier studies and 7-points likert scale was used where $1=$ 'Strongly disagree' to $7=$ 'Strongly agree'.

TL was measured based on 03 dimensions including active management by exception, contingent reward, and passive management by exception dimension. This scale was consist on 13 items (Omoankhanlen et al; 2014).

Work meaningfulness, the moderating variable of the study was measured using 06 items (Douglas et al., 2004). Supervisor rated job performance, the dependant variable of the study was measured using 07 items (William \& Anderson ; 1991).

\section{Data Analysis}

\section{Reliability Analysis}

The relaiability test was conducted. CR ranged from .89 to .94 against the standard value of greater than 0.60 . Thus, all the constructs of the study are reliabe.

\section{Data Analysis Techniques}

Data were analyzed using SPSS, Process Macro by Hayes. Correlation analysis and Confirmatory factor analysis was done before SEM.

Square root of AVE shows the values between 0.77 to 0.86 . Hence, all the values are greater than standard value of 0.70. Moreover, CR values ranges between 0.89-0.94 therefore, it further confirmed the reliabilty of the constructs.

CFA reveals the discriminant valididty of all the latent variables. Morevoer, moderation was done using PROCESS macro. 
Descriptive Statistics

Table I: - Frequency Distribution (GENDER \& AGE)

\begin{tabular}{|c|c|c|c|c|c|}
\hline \multirow{4}{*}{\multicolumn{2}{|c|}{ Gender }} & \multirow[b]{2}{*}{ Male } & $\begin{array}{c}\text { Frequenc } \\
\mathbf{y}\end{array}$ & Valid percentage & $\begin{array}{l}\text { Cumulative } \\
\text { percentage }\end{array}$ \\
\hline & & & 160 & 80.0 & 80.0 \\
\hline & & Female & 40 & 20.0 & 100.0 \\
\hline & & Total & 200 & 100.0 & \\
\hline & & $26-30$ & 65 & 32.5 & 32.5 \\
\hline & & 31-35 & 60 & 30.0 & 62.5 \\
\hline & & $36-40$ & 55 & 27.5 & 90.0 \\
\hline Age & & 41-45 & 20 & 10.0 & 100.0 \\
\hline & & Total & 200 & 100.0 & \\
\hline
\end{tabular}

Table 1 shows representation of both male and female faculty members where $20 \%$ were female and $80 \%$ were male respondents. Moreover, data shows the people of different age groups from the age of 26 to 45 years.

Table 2: Mean, Standard Deviation \& Correlation

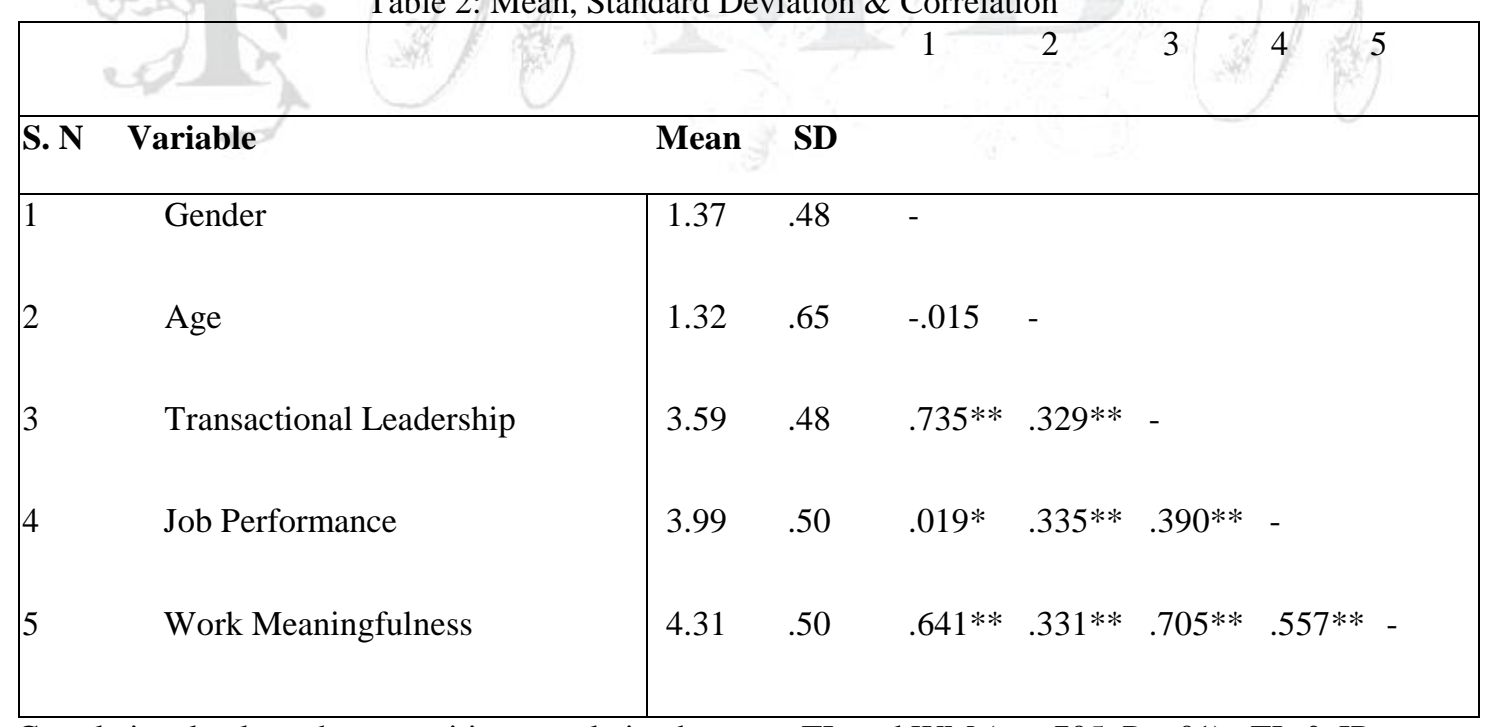

Correlational values shows positive correlation between TL and WM $(\mathrm{r}=.705, \mathrm{P}<.01)$, TL \& JP $(\mathrm{r}=0.390, \mathrm{P}<.01)$ and $\mathrm{WM} \& \mathrm{JP}(\mathrm{r}=.557, \mathrm{P}<.01)$. 
Table 3: Factor Loadings, Reliabilities \& AVEs

\begin{tabular}{|c|c|c|c|c|c|c|c|c|}
\hline Items & Fact & r Loadi & & & & AVE & $\sqrt{ } \mathbf{A V E}$ & CR \\
\hline & CONR & АCTM & PASM & WM & JP & & & \\
\hline TL.1 & .88 & & & & & & & \\
\hline TL. 2 & .85 & & & & & & & \\
\hline TL. 3 & .87 & & & & & & & \\
\hline TL.4 & .80 & & & & & & & \\
\hline TL. 5 & .91 & & & & & .74 & .86 & .94 \\
\hline TL. 6 & & .84 & & & & & & \\
\hline TL. 7 & & .89 & & & & & & \\
\hline TL. 8 & & .80 & & & & & & \\
\hline TL.9 & & .88 & & & & .73 & .85 & .91 \\
\hline TL. 10 & & & .80 & & & & & \\
\hline TL. 11 & & & .86 & & & & & \\
\hline TL.12 & & & .90 & & & & & \\
\hline TL.13 & & & .89 & & & .74 & .86 & .92 \\
\hline WM.1 & & & & .70 & & & & \\
\hline WM.2 & & & & .72 & & & & \\
\hline WM.3 & & & & .81 & & & & \\
\hline WM.4 & & & & .79 & & & & \\
\hline WM.5 & & & & .80 & & & & \\
\hline WM.6 & 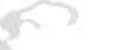 & & & .77 & & .59 & .77 & .89 \\
\hline JP.1 & & & & & .80 & & & \\
\hline JP.2 & & & & & .79 & & & \\
\hline JP.3 & & & & & .70 & & & \\
\hline $\begin{array}{l}\text { JP.4 } \\
\text { IP } 5\end{array}$ & & & & & $\begin{array}{r}.76 \\
88\end{array}$ & & & \\
\hline JP.6 & & & & & .82 & & & \\
\hline JP.7 & & & & & .75 & .62 & .79 & .92 \\
\hline
\end{tabular}

Note: $* *$ Correlation is significant at the 0.01 ( 2 -tailed)

\section{Structured Equation Modeling}

Ensuing measurement model, Structural model was run through SEM. Gender \& Age being the control variables were controlled.

Figure II reveals that Hypothesis 1 is confirmed. The $\beta$ value of 0.41 approves one-unit change in TL has brought 0.41 units change in JP of the faculty members. Hence, TL strongly effect on the supervisor rated job performance of the faculty members and proves H1 of the study Figure 2: Direct Effect Model

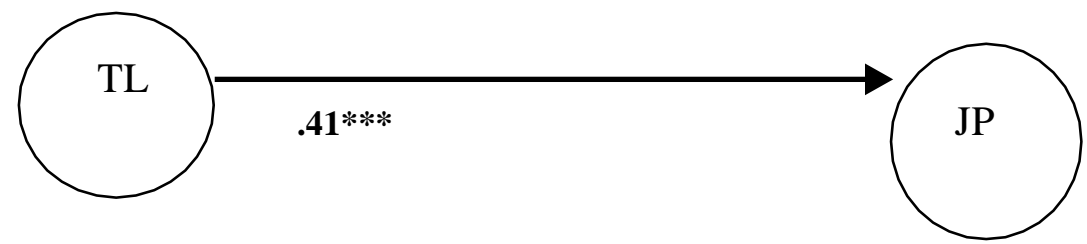

Figure 2: Direct Effect Model (Transactional Leadership \& Supervisor rated Job Performance) 


\section{Moderated Regression Analysis}

Table 5: Moderation Analyses predicting Job Performance

\begin{tabular}{|lccc|}
\hline & $\mathrm{b}$ & $\mathrm{SE}$ & $\mathrm{T}$ \\
\hline \multirow{2}{*}{ Constant } & \multicolumn{2}{c|}{ Dependent variable } & Job Performance \\
\cline { 2 - 4 } & .312 & .488 & 1.035 \\
Transactional Leadership & .408 & .201 & 3.469 \\
Work Meaningfulness & .478 & .148 & 3.014 \\
Interaction effect (TL x WM) & .135 & .050 & 2.248 \\
\hline
\end{tabular}

In Table 5, interaction of transactional leadership and work meaningfulness showed significant beta value of $(\beta=0.14, p<0.05)$. Hence, Work meaningfulness moderates and therefore hypothesis 2 is accepted.

\section{Discussion \& Conclusion}

The main purpose of the study was to investigate the interactive effects of transactional leadership and work meaningfulness on job performance of faculty members $(\mathrm{H} 1 \& \mathrm{H} 2)$. The study filled the gap by introducing moderating role of work meaningfulness between transactional leadership and job performance as previously no study was found where this relationship was examined. Therefore, it also contributes in the existing body of literature in the field of management, HRM and social sciences. Findings prove that when leader is transactional and task oriented on one side. While faculty members have work meaningfulness on other side. Then, both jointly influence and increase the job performance of the faculty members.

\section{Implications of Study}

Findings show the significance of transactional leaders in the education sector of Pakistan. Moreover, its importance to relate leadership with work meaningfulness. The present study is helpful for policy makers, managers and administrators of education institutions to supervise their subordinates. It is very helpful to understand how transactional leadership style needs to implement and adopt to improve the performance of subordinates.

It is proven that transactional leadership is very helpful in performing operational duties. The study is helpful for leadership of the educational institutions/universities to decide about the nature of faculty members who should be hired. The study will help to improve the performance of faculty members which will be ultimately beneficial for the students of these institutions.

\section{Limitations and Future Research}

This study incorporates only transactional leadership stlyle due to time constraint, future researchers can incorporate mix of leadership style to investigae or compare the results. The research only covers the education institutes of Islamabad, Rawalpindi, Sialkot and Lahore. Future research can be conducted into different sectors or by expanding the population. 


\section{References}

Alrowwad, A. A., \& Abualoush, S. H. (2020). Innovation and intellectual capital as intermediary variables among transformational leadership, transactional leadership, and organizational performance. Journal of Management Development. 39(2): 196-222

Antonakis, J., \& Day, D. V. (2018). Leadership: Past, present, and future.

Bass, B. M., \& Avolio, B. J. (1990). Transformational leadership development. Palo Alto, CA.: Consulting Psychologists Press.

Bass, B.M. 1997. "Concepts of Leadership". In Vecchio, R.P. (ed). Leadership: Understanding the Dynamics of Power and Influence in Organizations. Notre Dame: University of Notre Dame Press.

Behling, O. and Mcfillen, J. 1996. "A syncretical model charismatic/transformational leadership", Group and Organization Management, 21(2): 120-160.

Barrs, J. (2005). Factors contributed by community organizations to the motivation of teachers in rural Punjab, Pakistan, and implications for the quality of teaching. International Journal of Educational Development, 25(3), 333-348.

Blankenship, S. (2010). The consequences of transformational leadership and/or transactional leadership in relationship to job satisfaction and organizational commitment for active duty women serving in the Air Force Medical Service. Nova Southeastern University. United States, Florida:.

Bligh, M. C., Kohles, J. C., Pearce, C. L., Justin, J. E., \& Stovall, J. F. (2007). When the romance is over: Follower perspectives of aversive leadership. Applied Psychology, 56(4), 528-557.

Burns, J. M. (1978). Leadership. New York: Harper and Row Publishers.

Chang, S., \& Lee, M. S. (2007). A study on relationship among leadership, organizational culture, the operation of learning organization and employees' Job Satisfaction. 14(2), 157.

Crant, J. M. (2000). Proactive behavior in organizations. Journal of Management, 26, 435-462.

Davies, L., \& Iqbal, Z. (1997). Tensions in Teacher Training for School Effectiveness: The Case of Pakistan. School Effectiveness \& School Improvement, 8(2), 254-266.

De Clercq, D., Haq, I. U., \& Azeem, M. U. (2019). Why happy employees help. Personnel Review.

DeHart-Davis, L., \& Pandey., S. K. (2005). Red Tape and Public Employees: Does Perceived Rule Dysfunction Alienate Managers? Journal of Public Administration Research and Theory, 15(1), 133148.

Demirtas, O., S. T. Hannah, K. Gok, A. Arslan, and N. Capar. 2017. "The Moderated Influence of Ethical Leadership, via Meaningful Work, on Followers' Engagement, Organizational Identification, and Envy." Journal of Business Ethics 145 (1): 183-199

Dess, G. G., Picken, J. C., \& Lyon, D. W. (1998). Transformational leadership. Journal of Managerial Issues, 10, 30-45.

Douglas, R. M., Richard, L. G., \& Lynn, M. H. (2004). The psychological conditions of meaningfulness, safety and availability and the engagement of the human spirit at work. Journal of Occupational and Organizational Psychology, 77, 11-37.

Duffy, M. K., K. L. Scott, J. D. Shaw, B. J. Tepper, and K. Aquino. 2012. “A Social Context Model of Envy and Social Undermining." Academy of Management Journal 55 (3): 643-666

Foosiri, P. (2002). An empirical study of organizational commitment and antecedents of Thai employees within the American chamber of commerce in Thailand.

Fullan, M. (2000). School-based management: Reconceptualizing to improve learning outcomes. School Effectiveness and School Improvement, 11(4), 453.

Frese, M., \& Fay, D. (2001). Personal initiative: An active performance concept for work in the 21st century. In B. M. Staw \& R. L. Sutton. Research in organizational behavior. Stamford, 23, 133-187.

Ghahreman, T. K. (2005). The relationship between leadership style and organizational culture of schools, the creative faculty of the departments of physical education in public schools, Mission PhD, . University of Teacher Education.

Goderya-Shaikh, F., Madden, M., \& Saad, I. (2006). Ensuring quality during monitoring of the learningenvironment of government primary schools achieved through the UEI-PDP for teachers and head teachers. Educational Research and Review, 1(9), 328336. 
Harpaz, I., Honig, B., \& Coetsier, P. (2002). A cross-cultural longitudinal analysis of the meaning of work and the socialization process of career starters. Journal of World Business, 37, 230-244.

Hellriegel, D., Jackson, S.E. and Slocum, J.W. 1999. Management. Cincinnati: South-Western College Publishing.

Hellriegel, D. and Slocum, J. 1996. Management (7th Edition). Cincinnati: SouthWestern College Publishing.

Howell, J. M., \& Avolio, B. J. (1993). Transformational Leadership, Transactional Leadership Locus of Control and Support for Innovation: Key Predictors of Consolidated Bossiness Performance. Journal of Applied Psychology, 78(1), 891-902.

Ishtiaq, H. (2009, June28,2009). Teachers can make a difference. The Dawn. Retrieved September20,2009, fromwww.dawn.com

Islam, T. S., Saif Rehman, \& A., I. (2013). Investigating the Mediating Role of Organizational Politics between Leadership Style and Followers, Behavioral Outcomes. Business Strategy, 14, 80-96.

Jamal, M. (2007). Type-a behavior in a multinational organization: a study of two countries. Stress and Health, 23(2), 101-109.

Johari, J., Yean Tan, F., \& Tjik Zulkarnain, Z. I. (2018). Autonomy, workload, work-life balance and job performance among teachers. International Journal of Educational Management, 32(1), 107-120.

Jaussi, K. S. (2007). Attitudinal commitment: A three-dimensional construct. Journal of Occupational and Organizational Psychology, 80, 51-61.

Kark, R. (2004). The Transformational Leader. Who is (s) he? A Feminist Perspective. Journal of Organizational Change Management, 17(2), 160-176.

Lin, J. S. J., C., 1. S., \& Y., 1. B. (2010). The moderating affects of employee personality characteristics on organizational commitment during periods of organizational change. Afr. J. Bus. Manage, 4, 36813690.

Longe, O. J., 2014. Leadership style paradigm shift and Organisational performance: A case of the Nigerian Cement Industry. African Research Review, 8(4), pp. 68-83.

Maynard, M. Travis, Lucy L. Gilson, and John E. Mathieu. 2012. "Empowerment-—Fad Or Fab? A Multilevel Review of the Past Two Decades of Research." Journal of Management 38 (4): 1231-1281.

Meyer, J. P., Stanley, D. J., Herscovitch, L., \& Topolnytsky, L. (2002). Affective, continuance and normative commitment to the organization: A meta-analysis of antecedents, correlates, and consequences. Journal of Vocational Behavior, 61, 20-52.

Mwita, J. I. (2000). Performance Management Model, a system-based approach to system quality. The International journal of public sector management, 13(1), 19-12.

Memon, M., Ali, R. N., T.Simkins, \& Garrett, V. (2000). Understanding the head teachers' role in Pakistan: emerging role demands, constraints, and choices. International studies in Educational Administration, $28(2), 48-55$.

Mings, L.L. and Schwab, D.P. 1973. Performance in Organisations: determinants and appraisal. Glenview: Scott, Foresman and Company.

Mosadeghrad, A. M. (2003). Principles of Health Care Administration. Tehran.

Mowday, R. T., Steers, R. M., \& Porter, W. L. (1992). Employee, organization linkages. New York: New York Academic Press.

N.J., A., \& J.P., M. (1996). Affective, continuance, and normative commitment to the organization: An examination of construct validity. J. Voc. Behave, 49, 252-276.

Nazem, F., \& S., H. (2013). Providing a Structural Model of Organizational Justice Based on Transactional and Transformational Leadership at Islamic Azad University. Journal of A New Approach in Educational Administration, 4(1), 51-66.

Omoankhanlen, J. A., Ajienka, M. F., \& Oloda, O. F. (2014). Transactional Leadership Style and Employee Satisfaction in Nigerian Banking Sector. European Journal of Business and Management, 6(26), 1423.

Oplatka, I. (2004). The Principalship in Developing Countries: Context, Characteristics and Reality. Comparative Education, 40(3), 427-448. 
Parker, S. K. (2000a). From passive to proactive motivation: The importance of flexible role orientations and role breadth self-efficacy. Applied Psychology An International Review, 49, 447-469.

Ristow, A., Amos, T. and Staude, G. 1999. "Transformational leadership and organizational effectiveness in the administration of cricket in South Africa, South African Journal of Business Management, 30(1): $1-5$.

Rutter, G. 1995. "Leadership: directing people for their genuine long-term good", Human Resource Management, 10(2): 27-28.

Sarwat, N., Hayat, K., Qureshi, J. A., \& Ali, M. (2011). Impact of strategic leadership on organizational performance, in the context of job satisfaction and organizational commitment, evidence form educational institutions of Pakistan. Interdisciplinary Journal Of Contemporary Research In Business, 3(4), 658-675.

Schriesheim, C., Castro, S., \& Cogliser, C. (1999). Leader-member exchange (LMX) research: A comprehensive review of theory, measurement, and data-analytic procedures. Leadership Quarterly, 10, 63-113.

Simkins, T. (2003). School leadership in Pakistan: Exploring the Head teacher's role. School Effectiveness and School Improvement, 14(3), 275.

SS Khanka. (2006). Organizational Behavior. India: $S$ Chand Publishing. Retrieved from https://books.google.com.pk/books/about/Organisational_Behaviour.html?id=rnrsAZy6db4C\&redir_es $\mathrm{c}=\mathrm{y}$

Tsai., W. C., Chen., H. W., \& Cheng, J. W. (2009). Employee positive moods as a mediator linking transformational leadership and employee work outcomes. The International Journal of Human Resource Management, 20(1), 206-219.

Vincent, C., \& Sandra, B. (2013). An Examination of the Relationship between Authentic Leadership and Psychological Well-Being and the Mediating Role of Meaningfulness at Work. International Journal of Humanities and Social Science, 3(5), 171-183.

Vuori, T., San, E., \& Kira, M. (2012). Meaningfulness-making at work. Qualitative research in organizations and management, 7 (2), 231-248.

Walumbwa, F. O., \& Hartnell, C. A. (2011). Understanding transformational leadership-employee performance links: The role of relational identification and self-efficacy. Journal of Occupational and Organizational Psychology, 84(1), 153-172.

Whetten, D.A. and Cameron, K.S. 1998. Developing Management Skills (4th Edition). London: AddisonWesley Educational Publishers Inc.

Wrzesniewski, A., McCauley, C., Rozin, P., \& Schwartz, B. (1997). Jobs, careers, and callings: People’s relations to their work. Journal of Research in Personality, 31, 21-33.

Young, H. R., Glerum, D. R., Joseph, D. L., \& McCord, M. A. (2021). A meta-analysis of transactional leadership and follower performance: Double-edged effects of LMX and empowerment. Journal of Management, 47(5), 1255-1280. 